\title{
PRESIDENT'S LETTER.
}

I939.

DEAR SIR,-Early this year the Council decided that annually the newly elected President should open the Autumn Session by an address, and it was to have been my great privilege to be the first to give such an address in October of this year. In this talk I had hoped to tell you something of the Council's intentions for the ensuing fifteen months.

It was hoped that next year would prove to be an important one in the history of the Royal Aeronautical Society. It had acquired new premises worthy of its prestige; it had an assured income for their maintenance, and it had decided upon holding an International Congress at Stratford-on-Avon in the summer of 1940. The Society would, therefore, assuredly take another step forward in its history of achievement.

But the coming of war has, of course, changed all this. The Council have now decided that I should write you a letter explaining what its action has been and the general policy upon which it has decided since the outbreak of hostilities.

It is appreciated that practically every member of the Society or their relatives will be playing some part or other in prosecuting the war, and that everyone's efforts will be concentrated on carrying this war through to the only possible conclusion, no matter what may be the cost.

The Council have asked me to wish Godspeed to all members in this National work in the sure knowledge and appreciation that the Royal Aeronautical Society, throughout all its branches and grades, is playing a vital part in the conduct of the war.

At the outbreak of war, the Council was called upon to take immediate steps to consider the general policy of the Society and have arrived at the following conclusions.

The archives and valuable papers of the Society have been moved from No. 4, Hamilton Place to a suitable place of safety in the country where they will remain until the cessation of hostilities.

No. 4, Hamilton Place, the new headquarters of the Society, will be kept open. Captain Pritchard, with a skeleton staff, will remain at No. 4, Hamilton Place. Some of the rooms, including the Library, will be available for the use of members until further notice.

If members have any spare time whatsoever, it is the Council's earnest desire that they should endeavour to make as much use as possible of Hamilton Place whenever opportunity offers.

The lecture programme for the coming Session has been cancelled. It is realised that in wartime everybody is so busy that it is impossible to give sufficient importance to lectures, and that many subjects cannot be discussed with adequate freedom. The Wilbur Wright lecture, however, will take place next May.

If the war continues for a long period, it is hoped that we may be able to consider some curtailed form of lecture programme for the following session.

All the arrangements for the forthcoming International Congress at Stratfordon-Avon, which were making excellent progress, have had to be cancelled, and 
the services of Colonel Edwards, who was doing good work on behalf of this conference, have had to be dispensed with for the duration of hostilities.

It is most important that the subscription list be kept up, and an endeavour made to increase the membership, and I hope that all members will make a point of paying their subscriptions promptly.

I cannot possibly conclude this letter without referring to the magnificent generosity of a large number of members of the Aircraft and Allied Industries, which has enabled the considerable sum of $f_{109,202} 4 \mathrm{~s}$. od. to be collected. This will ensure that the Society can be continued on a proper financial basis.

I am sure you will agree that the grateful thanks of all members of the Society are due to those who have made this possible, and I would like to record the Council's high appreciation of this generous help. A list of the subscriptions towards the funds of the Society will be found in the current issue of the Journal.

It is hoped that it will be possible to make another statement in regard to the activities of the Society early next year.

With all good wishes,

Yours truly,

A. H. R. FedDEN,

President. 